Orissa Journal of Commerce

Vol. 42, Issue 3, July-September 2021

ISSN: 0974-8482

(C) OJC India. All Right Reserved

URL: www.ojcoca.org

DOI: https://doi.org/10.54063/ojc.2021.v42i03.10

\title{
A Study on the Relationship between Financial Well-Being and Self-Control
}

\author{
Santosha Kumar Mallick ${ }^{1 *}$ and S.S. Debasish ${ }^{2}$ \\ ${ }^{1}$ Research Scholar, Department of Business Administration, Utkeal University, Bhubaneswar, Odisha. E-mail: santoshmal@gmail.com \\ ${ }^{2}$ Associate Professor, Department of Business Administration, Utkal University, Bhubaneswar, Odisha. \\ E-mail: sathyaswaroop2000@yahoo.com \\ ${ }^{*}$ Corresponding Author
}

To cite this paper

Mallick, S. K., \& Debasish, S.S. (2021). A Study on the Relationship between Financial Well-Being and Self-Control. Orissa Journal of Commerce. 42(3), 120-133.

Keywords

Financial well-being, Self-control, Financial intervention, Financial knowledge, Financial performance

JEL Classification D14, D91, G41

\begin{abstract}
The prime objective of the human being in their household is to achieve financial well-being, because well-being is related to its mental satisfaction. In this analysis, various variables influencing a related financial well-being model of the family are identified and examined. An online survey is conducted to study the financial behaviour, subjective well-being, self-control, trust and demographic variables. Our experiments extend the use of behavioural life cycle theory to achieve general financial benefits in addition to savings behaviour. The study findings suggest that socioeconomic well-being has substantial impact on finance, financial knowledge, financial status, and marital status. Financial intervention profoundly impacts the consequences of financialliteracy, financial-behaviour and enforcement of financial-welfare. Marital status also increases the financial well-being effect on financial literacy but does not improve financial well-being. Individuals with high self-control are more likely to save money from each quest and improve their overall financial performance and investments.
\end{abstract}

\section{Introduction}

The impact of psychological factors on financial behavior is an increasingly popular topic for researchers around the world. Their focus, however, is shifting from financial capability to financial well-being. There are many in-depth studies on the impact of psychological factors on financial behavior and on antecedents of financial well-being. The majority of research focuses on perceptual variables that influence financial behavior, with little attention paid to non-cognitive components such as self-control, obligations, and social values (Lusardi, 2008).

A critical question which needs utmost attention is financial welfare. Progress in improving financial well-being will lead to poverty reduction. For a developing country such as India, which is striving to alleviate poverty, this analysis of financial welfare is becoming increasingly relevant. The World Bank report shows that the marginal decline in 2018 also falls below the poverty line of 25.9 million or $9.8 \%$ 
of the Indian population, down from $10.6 \%$ on average in 2017. Financial well-being is a state where people can meet their desires, feel secure in the future, and live to meet uncertain future needs. Increased financial security thus means alleviating starvation and affecting human life. Financial wellbeing can affect the health and mental health of an individual. Problems of financial well-being can exacerbate emotional and social deprivation (Kim, et al., 2016, Shim and Serido, 2009). Different models of research have been developed for financial welfare (Porter and Garman, 1993). The analysis describes the effects of demographic considerations (gender, race, schooling, and employment), analytical features, perceived characteristics (income and wealth), and measured attributes of financial wellbeing (external financial experiences and future financial expectations). The analysis demonstrates the impact on financial wellbeing of a demographic aspect, its objective characteristics, its perceived features and qualities. (Sabri et al., 2013) develop a financial well-being paradigm that focuses on the mediating aspect of financial literacy. They illustrate that financial well-being is affected by saving practices, financial society by parents and faith, and financial literacy. They also concluded that financial wellbeing is dependent on financial happiness, financial condition, financial conduct, financial position and financial understanding.

Across countries, financial locus of control and confidence has significant effects on financial well-being (Kempson, 2018). Taking personal responsibility for financial results (internal control) rather than blaming others or the environment is what locus of control entails (external control). Confidence in the Kempson study is like specific financial knowledge, a significant forecaster of financial wellbeing (Riitsalu and Murakas, 2019). A confident man is more likely to take active care of your financial well-being.

Previously, most research focused on cognitive elements that influence financial behaviour, with little attention paid to non-cognitive aspects such as self-control, obligations, and cultural values (Lusardi, 2008). Recent study has focused on determining the impact of financial conduct in the relationship between individual self-control and financial well-being (Kahneman, 2011). To bridge the gap between self-control and financial well-being, the authors investigated the impact of Financial Behavior, Financial Experience (FE), Financial Status (FS), and Internal Locus of Control (LC) on the financial well-being of the Indian population.

For measuring self-control and future time perspective, participants were asked to score their level of agreement or disagreement with eight propositions ranging from "I have a hard time breaking bad habits" to "I like planning and preparing for the future". Analysing the responses from 854 individuals, we find both SC and FTP to have an enormous consequence on economic well-being. People with high self-control have less current money management stress (CMMS). Future oriented people have enhanced expected future financial security (EFFS). The consequence of these emotional features on both components of financial well-being is larger than of the socio-economic variables. Only having more than one year's income set aside in savings has a bigger effect on CMMS than selfcontrol. For EFFS, more than 7 months' income in savings and the highest household income level have a larger effect than future time perspective. All other socio-economic factors have a substantially smaller effect. 


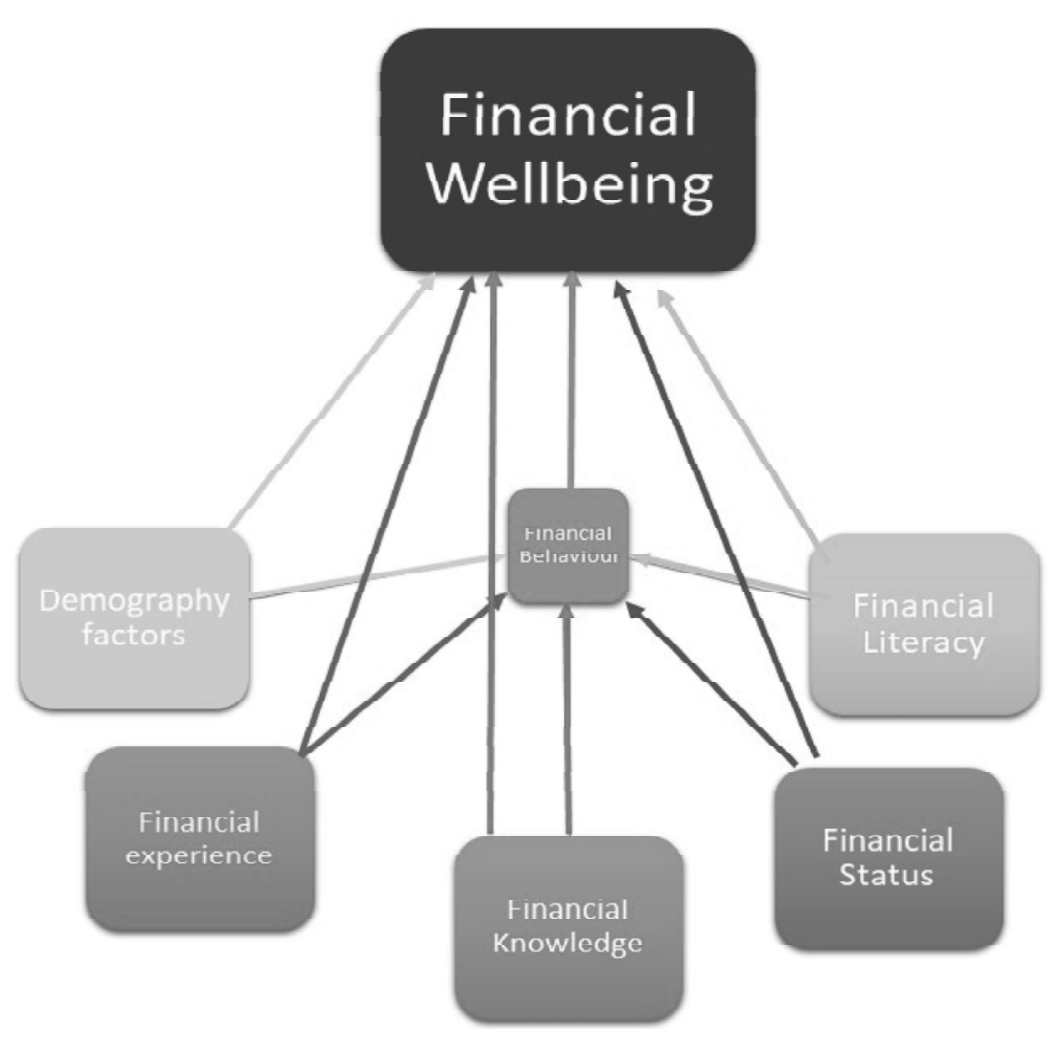

Figure 1: Model for Financial well-being

\section{Review of Literature}

\subsection{Self-control and Financial Behavior}

The financial behaviour of all economic components is influenced by self-checking. In self-control, person is regarded as an organization (Thaler and Shefrin, 1981). Conflicts between acts and sentiments sometimes confuse people, but inner confidence builds on self-control (Baumeister, 2002). Biljanovska and Palligkinis (2018) proposed all three elements of self-control; organizing, self-control and commitment, strongly linked to the net worth financial hardship. Self-control allows in future being weal thy or dominant in decision making, high willpower, and achievement. Failure to regulate one's results in unreasonable decision-making, mistrust becomes behavioral catastrophe. What people plan and assess accurately now, depends on their financial future.

People typically postpone their goals, sometimes attempt to limit their actions with rigid guidelines and deadlines to attain better results, however, too stringent conditions also lead to less regulation, as these laws are not defined optimally. Even self-control issues are explained by the Behavioral Life Cycle (BLC) concept (Shefrin and Thaler, 1988). The Behavioral Life Cycle theory states that public 
relies on existing issues and benefits instead of long-term gains. By splitting money into groups i.e. current income, current assets and potential profits, people use available resources (Thaler, 1985). People do not monitor their revenues because they invest more on existing needs than they save on pensions and other future necessities (Moffitt et al., 2011).

A marshmallow experiment was performed by Mischel and fellow researchers on school children. They gave students snacks and instructed them to not consume a bigger snack for the next 15 minutes and to see what students had their own power and what they don't have. Over $60 \%$ of students didn't have a new lunch and enjoyed treats for 15 minutes. The 15-minute waiting students had bigger treats and felt recompensed. This experiment has shown that people sometimes cannot manage their cognitive pit and make short-term appreciation choices that are less worthwhile (Angeles and Uni, 1972). Subsequent results found students waiting for greater rewards were more competitive with higher revenues and properties in life and fewer drug addictive and unhealthy behavior because they had improved self-checking. Many who manage themselves well take sound financial judgment (Moffitt $e t$ al., 2011).

\subsection{Financial Behavior, Self-Control and Well-Being}

Individuals with more leverage of themselves have better financial conduct and have good financial treatment. You invest your resources optimally (Kiyosaki, 2012). They waste no money on frivolous things and sports. For several years, people with strong self-control have led the planet today and this guide to greater financial well-being. Cognitive people often plan their budgets to meet those targets and predictable expenditures (Kahnemann, 2011). In accordance with their own behavior, planners and doers, Thaler and Shefrin (1981) have divided people into two groups. Planers deal with lifetime usefulness and doers are vain and short-sighted and are only available for short periods.

The Office for Consumer Financial Protection (CFPB)' released a study 'The goal of financial education (2015)" focused on financial well-being described as "The condition where you are: take care of regular, monthly finances; withstand a financial shock; monitor to reach your finances objectives".

Financial well-being is an aim to live a rich and stable, economically and emotionally strong lives through self-regulation. Feeling less self-control about the financial condition leads to anxiety. People also feel nervous and worried about their financial health as they make self-control and financial choices, when they invest their money (Oechssler et al., 2009).

Optimism has a significant effect on financial activities and happiness. Confident individuals are being sound at achieving their ultimate life goals and becoming more concerned about their potential well-being. Massively optimistic, yet highly optimistic, financial behaviors are violent, not thought to be good for financial happiness (Puri et al., 2007). Stromback et al. researched the way in which selfcontrol predicts financial wellbeing on the Swedish population and determined that the concept of BLC applies to both investment and general financial behavior. People with strong self-control put aside additional money to improve financial conditions now or in the future (Strömbäck et al., 2017).

Financial considerations have greater influence than non-financial factors on critical thought. These psychological elements influence autonomy and financial activities that lead to financial wellbeing. The effects of financial conduct and management of self-regulation and financial literacy is 
being discussed in this article. In the conference paper, Lusardi (2008) investigates why people with poorer financial literacy are not aware of efforts to save money and pension schemes. Without literacy, the absence of financial and factual information cannot make rational choices. Teens and adults do not have basic decision-making capabilities (Mandell and Klein, 2009). Consumer debt is linked to recognition of self-control and financial illiteracy (Gathergood, 2012).

\section{Objectives and Hypotheses of the Study}

\subsection{Objectives of the Study}

The objective of this study is to identify and examine various variables influencing a related financial well-being model of the family and household.

The specific objectives of this study are:

- To study the impact of socioeconomic well-being on finance, financial knowledge, financial status, and marital status.

- To study the impact of financial intervention on the consequences of financial-literacy, financial-behaviour and enforcement of financial-welfare.

- To study the relationship among marital status, financial literacy and financial well-being.

- To study the relationship between self-control and overall financial performance and investments.

\subsection{Hypotheses of the Study}

A variety of elements have been shown to have an influence on financial stability, including financial experience. Financial history shows how much an individual used financial resources, including loans, deposits, financing, market capital securities and insurance (Hogarth and Hilgert, 2002). Financial experience enables someone to control their finances properly (Brilianti and Lutfi, 2020; (Lewis et al., 2008). An individual who has sound investment history strengthen his pecuniary well-being. Somebody who has understanding in funds management, including investment, pension and credit management, understands financial goodness more deeply (Sabri et al., 2012).

$\mathrm{H}_{01}$ : The greater the economic insight, the better is the financial well-being.

Economic literacy is a key aspect for the evaluation of financial wellbeing. For financial administration, financial know-how is important. People with strong financial expertise like to invest money and invest better. Financial experience should also be used to enhance financial well-being. People with improved understanding have a higher accumulation of capital and a higher financial perception.

$\mathrm{H}_{02}$ : The more financial intelligence, the greater is the financial well-being.

There should be no difference between financial knowledge and financial position. Financial status represents an individual or a family's financial situation based on wages, wealth and debt (Gerrans et al., 2014). In deciding a family's financial status, the income level is a significant factor. The higher is the household income, the healthier is the financial situation of the family (Hsieh, 2004). This affects the financial well-being of the family positively. Conversely, debt is a duty which the family must satisfy from their income or property. The larger is the loan, the larger will be the sum payable. The higher the 
debt-to-income ratio, the poorer will be the health of the household, or in other words, the wealthier a family will be the lower the debt ratio.

$\mathrm{H}_{03}$ : The better the monetary condition, the greater is the financial well-being.

The economic happiness often depends on how an individual sees its status as a factor. An individual with an internal influence locus thinks everything depends on what he and his relatives have achieved, not on external influences or destiny. Persons with an internal control center are attempting to increase their finances, and they don't want to use the mercy of anyone for their performance. Persons with good power will be more able to plan and be responsible for their decisions. Consequently, their financial problems are less concerned and financially more satisfactory.

$\mathrm{H}_{04}$ : The greater the internal management locus, the healthier is the financial well-being.

The effect on financial satisfaction of these variables is reported by Joo and Grable (2004). To put it another way, financial action acts as a buffer between financial status and financial experience. Those with better financial skills seems to have more effective retirement funds, have less debt burden and have a more wealth accumulation. This positive financial performance improves financial well-being more. Financial activity can also affect the locus of financial well-being regulation. The sense of selfcontrol will change the intent to behave according to a theory of expected conduct and then is expressed in the actual actions. Internal monitoring locus promotes improved action in financial management.

Someone with an internal role in managing the budget needs to invest for the future and feel better in the future financial position. Self-control problems can result in unplanted expenditure (Gathergood, 2012), unsustainable debt (Achtziger et al., 2015, Kim et al., 2016). Promoting the internal financial management locus would boost the financial well-being.

$\mathrm{H}_{05}$ : Financial conduct mediates on financial well-being of financial history, financial awareness, financial condition and control position.

Marital status also influences the family's financial well-being. Married status helps someone to help plan their money as a way of their family responsibility (Headey and Wooden, 2004). This in fact leads to greater financial wellbeing for a married couple. In addition, the number of family dependents will damage the financial well-being of the family (Baek and DeVaney, 2004). To meet every day needs, a vast number of dependents need greater revenue. More family dependents are also more responsible and less liquid assets are available. The status of marital and family members would also decrease financial literacy and financial well-being. An individual having strong financial expertise and experience would be better inspired in future to fulfill their needs and boost family welfare. Combining family status and financial awareness will enhance financial fulfillment (Gerrans et al., 2014).

$\mathrm{H}_{06}$ : The influence of financial understanding on the well-being is moderated by marital status.

$\mathrm{H}_{07}$ : The marital status and number of children moderates the economic well-being effects of financial awareness.

The philosophical structure for analysis is presented in Figure 1. The emphasis of this investigation is on the financial well-being. Economic prosperity is based on financial awareness, monetary understanding, pecuniary circumstances and the locus of internal control.

Financial competence, expertise, position and internal control locus can influence economic and financial performance. In the final analysis, the demographic marital status component and the family's numbers balance the impact on financial wellbeing of financial expertise and financial experience. 


\section{Research Methodology}

An online survey was undertaken for this study from March 2020 till December 2020. A purposeful and convenience sampling methodology was used. These two technologies have been selected to promote the gathering of data and to ensure the selection of individuals according to study targets. The requirements for this analysis included a minimum monthly income of Rs. 50,000 for household's resident across state of Odisha (India). Questionnaires are circulated through online Google form. Among the households only 854 families have participated. There are 25 respondents, in particular with reference to home and minimum wages, who do not meet the survey requirements got eliminated. So a total of 829 participants' responses are included in the final sample for analysis.

Financial wellbeing is the endogenous component of this study. It is a situation in which an individual or a family can live happily with sufficient resources. Financial burden, financial happiness, financial ease, financial problems and financial trust included in the measurements of financial wellbeing in this analysis (Archuleta et al., 2013; Ng and Diener, 2014). The Likert scale from 1 to 5 measures these factors. Financial expertise, financial practice, financial position and internal control locus are exogeny in the analysis. The comprehension of financial principles i.e., financial knowledge of an individual has a foundation for financial management. This vector contains fundamental knowledge of finance, savings, loans, insurance and investment. The attribute is determined by the right response to the questions. Financial literacy is used for the measurement of the degree of uses of financial products. The vector measure of financial knowledge covers banking instruments, pension fund products and securities products. Financial condition is linked to the financial condition of an individual from the perspective of income and capital (Gerrans et al., 2014). Regulation is the point of view and control of a person's event.

This research uses the influence locus inside the respondents, namely self-control. Indicators provide management of expenditure, the resolution of financial issues and savings and investment implementation. The measure of data used is an interval scale of " 1 " for "never" and " 5 " for "always" with a Likert scale. Financial behaviour is the mediating component. It is the behaviour of an individual in their financial management and control. Indicators of this component include bill transfers, regular savings and investment funding, financial management, emergency funding provision, pension funds provision and insurance funds provision. The scale of this vector ranges from " 1 " for "never" to " 5 " for "always," and is calculated with "always." The attribute moderates the demographics and the amount of dependent is composed of marital status. A nominal scale score of " 1 " and " 0 " for married and unmarried respectively is taken for calculating marital status. The family number of employees is the number of families except the respondent.

\section{Data Analysis}

\subsection{Descriptive Statistics}

The descriptive statistics and the correlation between the variables are summarized in Table 1. It reveals that about $70 \%$ of respondents are married and having two dependents on average. The financial expertise of the respondents is usually very high, averaging $59.89 \%$. On average, six out of ten questions 
can be answered by the respondents. This is identical to Iramani and Lutfi (2021). There are two concerns about financial understanding, including the use of credit cards and advantages in terms of diversification. Only 30\% know that credit cards could extract cash from Automatic Teller Machines, and $29 \%$ realize that expanded portfolio reserves can mitigate risk. People with a mean of 3,375 and superior financial conduct, with mean score of 3,477 , are generally extremely weal thy.

Table 1: Descriptive Statistics \& Correlation among Variables

\begin{tabular}{lccccccccc}
\hline Variables & Mean & \multirow{2}{*}{$S D$} & \multicolumn{8}{c}{ Correlation } \\
\cline { 5 - 10 } & & & FW & FB & FE & FS & LC & FK & $S P$ \\
\hline Financial Well-being (FW) & 3.375 & 0.719 & & & & & & & \\
Financial Behavior (FB) & 3.477 & 0.839 & 0.590 & & & & & & \\
Financial Experience (FE) & 2.014 & 0.880 & 0.440 & 0.489 & & & & & \\
Financial Status (FS) & 2.664 & 1.541 & 0.429 & 0.306 & 0.423 & & & & \\
Locus of Control (LC) & 3.421 & 0.719 & 0.399 & 0.520 & 0.420 & 0.280 & & & \\
Financial Knowledge (FK) & 59.89 & 14.242 & 0.499 & 0.521 & 0.390 & 0.389 & 0.421 & & \\
Marital Status (MS) & 0.702 & 0.469 & 0.589 & 0.385 & 0.199 & 0.274 & 0.251 & 0.296 & \\
Family Dependent (FD) & 2.411 & 0.849 & 0.369 & 0.165 & 0.270 & 0.428 & 0.161 & 0.199 & 0.381 \\
\hline
\end{tabular}

At a coefficient of 0.590 , the relationship among financial behaviour and financial well-being is positive as estimated. Many of the factors examined correlate positively with financial welfare. The coefficient of correlation among variables remains below 0.6 , meaning that discriminant validity is not an issue. This is also confirmed by discriminatory checks of legitimacy according to the Fornell-Larcker criterion and correlation ratio Heterotrait-Monotrait (HTMT).

\subsection{Confirmatory Factor Analysis (CFA)}

Table 2 shows detailed results of Validity and reliability matrix for Confirmatory Factor analysis using convergence Validity and Internal consistency reliability. The validity test is an assessment scale for testing the validity of the tools in the sample. Both indicators are loaded more than 0.70 and the mean AVE is more than 0.50. Hence, the metrics used in this analysis are therefore accurate. Convergence testing is to determine the reliability quality of the score and measuring instruments. Both buildings possess more than 0.60 composite reliability score, and the alpha of Cronbach even reaches 0.60 . The questionnaire used in this analysis is also reliable since it is consistent and accurate in a good way.

Convergence Validity is checked using Average Variance-Extracted (AVE) and Standardized Factor Loading (SFL) while Cronbach's alpha (á) and Composite Reliability (CR) is used for internal consistency reliability testing. Our results reveal a Standardized Factor Loading (SFL) of greater than 0.40 and an AVE of greater than 0.50, indicating that the results are acceptable. Internal consistency (Cronbach Alpha) values should be high, with the greater the better (Cronbach and LJ, 1971). Because Cronbach Alpha implies that all indicators of a construct are equally connected to that construct (Werts et al., 
Santosha Kumar Mallick and S. S. Debasish

1974), and it tends to underestimate internal consistency dependability (McNeish, 2017), Composite Reliability (CR) should be employed to measure internal consistency (McNeish, 2017). In this study finding, the CR value is around 0.9 which is within acceptable value. The Average Variation Extracted (AVE), which should be equal to or greater than 0.50 , describes the variance in indicators of a construct (Sarstedt et al., 2017). Our results are more than 0.50, indicating that they are acceptable.

Table 2: Validity and Reliability Matrix

\begin{tabular}{lcccc}
\hline Various Parameter & $\begin{array}{c}\text { Convergence } \\
\text { Validity }\end{array}$ & $\begin{array}{c}\text { Internal } \\
\text { Consistency } \\
\text { Reliability }\end{array}$ \\
\hline & SFL & AVE & CR & $\alpha$ \\
\hline
\end{tabular}

\section{Financial Well-being (FW)}

1. Confidence in meeting emergency financial needs $\quad 0.798$

2. Concerns run into the daily living expenses 0.805

3. Comfort level on the present financial state $\quad 0.866$

4. Satisfaction with the current financial situation $\quad 0.867$

5. current financial pressure $\quad 0.809$

Financial Behavior (FB)

1. Prior-arrangement for insurance funds 721

2. Prior-arrangement for pension funds $\quad 0.769$

3. Prior-arrangement for emergency funds $\quad 0.84$

4. Control expenses 0.735

5. Prior-arrangement for monthly income for savings and investment $\quad 0.82$

6. Full bill payment $\quad 0.735$

7. On-time bill payments 0.729

Financial Experience (FE)

1. Investment products

0.762

2. Insurance products

3. Pension fund products

4. Banking products

0.775

0.814

0.762

Financial Status (FS)

1. Net Wealth

2. Monthly income

0.89

0.93

$0.693 \quad 0.915$

0.889

Internal Locus of Control (LC)

1. Realization of savings and investment 0.845

2. Spending beyond the plan 0.9

3. Dependence on financial solutions on others 0.799

4. Shopping for short-term enjoyment

0.779

Note: $\quad \alpha$ : Cronbach's alpha, CR: Composite Reliability, AVE: Average Variance-Extracted, SFL: Standardized Factor Loading. 
A Study on the Relationship between Financial Well-Being and Self-Control

\subsection{Discriminant Validity}

Moreover, to assess the discrimination-induced validity, this analysis uses Fornell-Larcker Criteria (FLC) and Heterotrait-Monotraits (HTMT) parameters (Fornell and Larcker, 1981). Table 3 indicates that the AVE's root exceeds the latent structure-based connection to Fornell-Larcker and that the HTMT ratio for both structures is smaller than 0.85 . Each structure thus is special and catches phenomena that are not depicted in the model by other buildings (Hair Jr et al., 2016). The HTMT ratios demonstrate how two variables are related (Henseler et al., 2015). The HTMT value should not exceed 0.85. (Kline, 2011). As indicated in Table 3, our findings are within the acceptable range.

Table 3: Discriminant Validity

\begin{tabular}{|c|c|c|c|c|c|c|c|c|c|c|}
\hline \multirow[t]{2}{*}{ Constructs } & \multicolumn{2}{|c|}{$F W$} & \multicolumn{2}{|c|}{$F B$} & \multicolumn{2}{|c|}{ FE } & \multicolumn{2}{|c|}{ FS } & \multicolumn{2}{|c|}{$L C$} \\
\hline & FLC & HTMT & FLC & HTMT & FLC & HTMT & FLC & HTMT & FLC & HTMT \\
\hline Financial Well-being (FW) & 0.833 & & 0.591 & 0.66 & 0.493 & 0.53 & 0.444 & 0.525 & 0.414 & 0.339 \\
\hline Financial Behavior (FB) & 0.509 & 0.66 & 0.765 & & 0.479 & 0.565 & 0.3 & 0.355 & 0.522 & 0.605 \\
\hline Financial Experience (FE) & 0.445 & 0.53 & 0.479 & 0.563 & 0.78 & & 0.42 & 0.53 & 0.413 & 0.511 \\
\hline Financial Status (FS) & 0.445 & 0.25 & 0.3 & 0.355 & 0.422 & 0.53 & 0.907 & & 0.275 & 0.339 \\
\hline Locus of Control (LC) & 0.414 & 0.479 & 0.522 & 0.606 & 0.444 & 0.51 & 0.275 & 0.339 & 0.803 & \\
\hline
\end{tabular}

Notes: HTMT: Heterotrait-Monotrait ratio, FLC: Fornell-Larcker criteria, LC: Locus of Control, FS: Financial Status, FE: Financial Experience, FB: Financial Behavior, FW: Financial Well-being.

All exogenous factors in the Financial Well-being Model in Table 4 have a substantial positive influence on financial well-being (FW), with the exception of the internal locus of control (LC) and the number of family dependents (FD), which have minor effects.

\subsection{The Financial Well-being Model}

Table 4: The Financial Well-being Model

\begin{tabular}{lccc}
\hline Relationship & Coefficient & Sig. (P value) & Supported (?) \\
\hline FE -> FW & 0.128 & 0.002 & YES \\
FK -> FW & 0.134 & 0.001 & YES \\
FS -> FW & 0.124 & 0.004 & YES \\
LC -> FW & 0.039 & 0.317 & NO \\
MS - > FW & 0.473 & 0.000 & YES \\
FD - > FW & 0.053 & 0.231 & NO \\
FB - PW & 0.215 & 0.000 & YES \\
R-Square & 0.647 & & \\
Adjusted R-Square & 0.678 & & \\
\hline
\end{tabular}

Notes: $\quad \mathrm{FE}=$ Financial Education; FK $=$ Financial Knowledge; FS=Financial Status; LC $=$ Internal Locus of Control; MS = Marital Status; FD = Family Dependent; FB = Financial Behavior; FW=Financial Wellbeing. 


\section{Results and Discussion}

Self-control impacts the financial conduct and well-being of individuals. Good self-management saves more money for their potential and is more likely to succeed in the future. Only by financial behavior the self-control affects financial wellbeing. Financial behavior has more effects on financial well-being than self-control. However, in self-control experiments the results are not as forecast. In India, there are also many things that can impact on self-regulation, such as gender, wages, education and the rural economy. Self-control analysis has been performed several times, now the studies need to find the linkages connecting self-control and financial activity correctly and control and moderate causes. Above all, self-regulation could influence financial well-being, but our research has found no such impact due to the control variables and moderators above mentioned. Financial literacy both actively and implicitly affects financial wellbeing through financial behavior. The questionnaires are from published sources, but $\mathrm{R}^{2}$ of the results, both in terms of financial conduct and well-being, are still small, showing that people continue to be driven by self-control and financial literacy. When governments' economic and developmental foundations create schemes that help citizens save and spend on their daily lives and save money, the savings of people will improve, and happiness of people will increase in the longer term.

Another challenge is that in the age of disruptive marketing, strategists from large firms have gained more experience and strength in the development of modern marketing techniques and how vulnerabilities and the application of human psychology to maximize business income. For businesses to revolutionize and to expand faster and more efficiently than ever before (Kumar, 2018), transformative marketing strategy is strong, though, but consumers are stuck in buying more and more without understanding whether you really need more. Both advertisers and economists there is a battle. Marketers aim to sell or not their goods and economists try to direct people into controlling their intuitive thinking and buying nothing except what is needed. People ought to be educated on how to invest. Politicians must rely on individuals' financial wisdom, since financially knowledgeable individuals spend money making better choices, not simply on luxury or frivolous stuff when they don't earn enough money (Kiyosaki, 2012).

\section{Conclusion}

A sample of 829 across Odisha (India) was studied with confirmatory factor analysis. Partial least squares (PLS) method is employed to test this model for financial welfare. The findings suggest that financial knowledge, financial status and marital status have a significant impact on financial well-being and financial literacy fosters healthier financial behavior, which improves financial well-being. There is not enough proof of financial well-being impacted by the locus and size of dependents. Financial activity mediates greatly the impact of financial behavior, financial awareness and the financial wellbeing management locus. Nevertheless, there is no proof that financial practice mediates financial well-being. Marital status also enhances the impact of financial literacy on financial well-being but does not enhance financial well-being.

This analysis has two key constraints. First, households with Rs. 50,000 a month minimum income are included in this survey. Future studies must concentrate on analyzing families with low incomes. 
Second, cross-sectional 2021 data may be used in this analysis. The phenomenon of adjustment of behavior over time, for example under normal economic circumstances and crises, is not captured. The probability of this change of behavior, particularly during the COVID-19 pandemic, can be investigated in future. From the the regulators' perspective, the outcomes of this study specify that, literacy and financial inclusion among the Indian population are the key points on which state and Indian government have to work for enhancing the financial well-being.

\section{References}

Achtziger, A., Hubert, M., Kenning, P., Raab, G., \& Reisch, L. (2015). Debt out of control: the links between self control, compulsive buying, and real debts. Journal of Economic Psycbology, 49, 141- 149. https://doi.org/ 10.1016/j.joep.2015.04.003.

Angeles, L., \& Uni, S. (1972). Cognitive and attentional mechanisms in delay of gratification 1.21(2): 204-18.

Archuleta, K. L., Dale, A., \& Spann, S. M. (2013). College Students and Financial Distress, Exploring Debt, Financial Satisfaction, and Financial Anxiety. Journal of Financial Counselling and Planning, 24(2), 50-62.

Baek, E., \& DeVaney, S. A. (2004). Assessing the baby boomers' financial wellness using financial ratios and a subjective measure. Family and Consumer Sciences Research Journal, 32(4), 321-348.

Baumeister, R. F. (2002). Yielding to temptation: Self-control failure, impulsive purchasing, and consumer. Journal of Consumer Research, 28(4): 670-76. Available: https://doi.org/ 10.1086/338209.

Biljanovska, N., \& Palligkinis, S. (2018). Control thyself: Self-control failure and household wealth. Journal of Banking and Finance, 92: 280-94. Available: https://doi.org/10.1016/ j.jbankfin. 2016.10.010.

Brilianti, T. R., \& Lutfi, L. (2020). Pengaruhpendapatan, pengalamankeuangandanpengetahua nkeuanganterhadapperilakukeuangankeluarga di kotaMadiun. Journal of Business and Banking, 9(2).

CFPB, Financial well-being: The goal of financial education (2015), available at https:/ files. consumerfinance.gov/ f/201501_cfpb_report_financial-well-being.pdf.

Cronbach, L. J. (1971). Test validation. In Thorndike, R. L. (Ed.), Educational measurement, 2nd ed. (pp. $443-$ 507). Washington, DC: American Council on Education. Available: https://ci.nii.ac.jp/naid/10017369036/.

Fornell, C., \& Larcker, D. F. (1981). Evaluating Structural Equation Models with Unobservable Variables and Measurement Error. Journal of Marketing Research, 18(1), 39-50. https://doi.org/10.2307/3151312.

Gathergood, J. (2012). Self-control, financial literacy and consumer over-indebtedness. Journal of Economic Psychology, 33(3): 590-602. Available: https://doi.org/ 10.1016/j.joep. 2011.11.006.

Gerrans, P., Speelman, C., \& Campitelli, G. (2014). "The relationship between personal financial wellness and financial wellbeing: a structural equation modelling approach", Journal of Family and Economic Issues, Vol. 35 No. 2, pp. 145-160.

Hair Jr, J. F., Hult, G. T. M., Ringle, C., \& Sarstedt, M. (2016). A primer on partial least squares structural equation modelling (PLSSEM). Sage publications.

Headey, B., \& Wooden, M. (2004). The effects of wealth and income on subjective well being and ill being. Economic record, 80, S24- S33.

Henseler, J., Ringle, C. M., \& Sarstedt, M. (2015). A new criterion for assessing discriminant validity in variance based structural equation modeling.115-35. Available: https://doi.org/10.1007/s11747-014-0403-8.

Hogarth, J. M., \& Hilgert, M. (2002). Financial knowledge, experience and learning preferences: Preliminary results form a new survey on financial literacy. Consumer Interests Annual, 48, 1-7. 
Hsieh, C.-M. (2004). Income and financial satisfaction among older adults in the United States. Social indicators research, 66(3), 249- 266.

Iramani, R., \& Lutfi, L. (2021). An integrated model of financial well-being: The role of financial behaviour. Accounting, 7(3), 691-700.

Joo, S.-h., \& Grable, J. E. (2004). The Financial Well-being Model n exploratory framework of the determinants of financial satisfaction. Journal of family and economic Issues, 25(1), 25-50.

Kahneman, D. (2011). Thinking, fast and slow. Farrar, Straus and Giroux.

Kempson, E. (2018). Financial Capability and Well-Being. An international comparison. National Research Symposium on Financial Literacy, Toronto.

Kim, J., \& Garman, E. T. (2003). Financial stress and absenteeism: An empirically derived model. Financial Counselling and Planning, 14(1), 31-42.

Kim, K. T., Lee, J. M., \& Hong, E. (2016). The role of self-control on retirement preparedness of US households. International Journal of Human Ecology, 17(2), 31-42.

Kiyosaki, R. T. (2012). Rich Dad Poor Dad. Available: http://www.csce001.com/edit_zoop/ uploadfile/system/ 20150408/20150408135309188.pdf.

Kline, R. B. (2011). Principles and practice of structural equation modelling. Guilford Press: New York.

Krejcie, R. V., \& Morgan, D. (1970). Determining sample size for research activities. Education and Psychological measurement, 607-10.

Kumar, V. (2018). Transformative marketing, The next 20 years. Journal of Marketing, 82(4): 1-12. Available: https://doi.org/10.1509/jm.82.41.

Lewis, J. K., Mimura, Y., Mauldin, T., Rupured, M., \& Jordan, J. (2008). Financial information: is it related to savings and investing knowledge and financial behaviour of teenagers? Journal of Financial Counselling and Planning, 19(2).

Likert, R. (1932). A technique for the measurement of attitudes. Archives of Psychology, 22: 5-55.

Lusardi, A. (2008). Household saving behavior, The role financial literacy, information and financial education programs. Nber working paper series. 13824. Available: https://doi.org/10.3386/w13824.

Mandell, L., \& Klein, L. S. (2009). The impact of financial literacy education on subsequent financial behavior. Journal of Financial Counselling and Planning, 20(206): 15-24. Available: https://doi.org/10.1.1.334.3320.

McNeish, D. (2017). Thanks coefficient alpha, we'll take it from here. Psychological Methods: Available: https:// doi.org/10.1037/met0000144.

Moffitt, T. E., Arseneault, L., Belsky, D., Dickson, N., Hancox, R. J., Harrington, H., \& Caspi, A. (2011). A gradient of childhood self-control predicts health, wealth, and public safety. 108(7): 2693-98. Available: https://doi.org/10.1073/pnas.1010076108.

Ng, W., \& Diener, E. (2014). What matters to the rich and the poor? Subjective well-being, financial satisfaction, and post materialist needs across the world. Journal of personality and social psychology, $107(2), 326$.

Oechssler, J., Roider, A., \& Schmitz, P. W. (2009). Cognitive abilities and behavioral biases. Journal of Economic Behavior and Organization, 72(1):147-52. Available: https://doi.org/10.1016/j.jebo.2009.04.018.

Porter, N. M. \& Garman, E. T. (1993). Testing a Conceptual Model of Financial Well-Being. Journal of Financial Counseling and Planning, 4, 134-164.

Puri, M., Robinson, D. T., Brav, A., Gervais, S., Hackbarth, D., Jenter, D., \& Tetlock, P. (2007). Optimism and economic choice $\$$ the authors are grateful for the comments and suggestions of around boot. Journal of Financial Economics, 86: 71-99. Available: https://doi.org/10.1016/j.jfineco.2006.09.003. 
A Study on the Relationship between Financial Well-Being and Self-Control

Riitsalu, L., \& Murakas, R. (2019). Subjective financial knowledge, prudent behaviour and income: The predictors of financial well-being in Estonia. International Journal of Bank Marketing, 37(4), 934-950. https:// doi.org/ 10.1108/IJBM-03-2018-0071.

Sabri, M. F., Cook, C. C., \& Gudmunson, C. G. (2012). Financial well being of Malaysian college students. Asian Education and Development Studies, 5(1), 153-170.

Sabri, M. F., Paim, L., Falahati, L., \&Masud, J. (2013). Determinants of employees' financial wellbeing: The moderation effect of work sectors. Malaysian Journal of Consumer and Family Economics, 16 (1), 91-105.

Sarstedt, M., Ringle, C. M., \& Hair, J. F. (2017). Partial least squares structural equation modelling. Handbook of market research. Available: https://doi.org/10.1007/978-3-319-05542-8_15-1.

Shefrin, H. M., \& Thaler, R. H. (1988). The behavioral life-cycle hypothesis. 26(October): 609-43.

Shim, S., \& Serido, J. (2009) Arizona Pathways to Life Success for University Students, Wave 1. Cultivating Positive Financial Attitudes and Behaviors for Healthy Adulthood. Tucson, AZ: University of Arizona. Retrieved from http://aplus.arizona.edu/wave1_report.pdf.

Strömbäck, C., Lind, T., Skagerlund, K., Västfjäll, D., \& Tinghög, G. (2017). Does self-control predict financial behavior and financial well-being? Journal of Behavioral and Experimental Finance, 14:30-38. Available: https:/ /doi.org/10.1016/j.jbef.2017.04.002.

Thaler, R. H. (1985). Mental accounting and consumer choice. Marketing Science, 4(3): 199-214. Available: https:/ /doi.org/10.1287/mksc.4.3.199.

Thaler, R. H., \& Shefrin, H. M. (1981). An economic theory of self-control'. Journal of Political Economy, 89(2):392406. Available: https://doi.org/10.1086/260971.

Werts, C. E., Linn, R. L., \& Jöreskog, K. G. (1974). Intraclass reliability estimates, Testing structural assumptions. Educational and Psychological Measurement, 34(1): 25-33. Available: https://doi.org/10.1177/ 001316447403400104 . 